\title{
Rice and Wheat Tariff Impact in Bangladesh: CGE Analysis Using Gtap Model
}

\author{
Syed Shoyeb Hossain ${ }^{1} \&$ Huang Delin ${ }^{1}$ \\ ${ }^{1}$ The Institute of Agricultural Economic and Development, The Chinese Academy of Agriculture Science, \\ Beijing, China \\ Correspondence: Huang Delin, The Institute of Agricultural Economics and Development, Chinese Academy of \\ Agricultural Sciences, 12 Zhongguancun Nandajie, Haidian District, Beijing, 100081, China. Tel: \\ 86-10-8210-6167; 186-1210-5186. E-mail: huangdelin@caas.cn
}

Received: April 17, 2019

doi:10.5539/jas.v11n10p63
Accepted: May 26, 2019 Online Published: July 15, 2019

URL: https://doi.org/10.5539/jas.v11n10p63

The research is financed by project of "Open Laboratory of national agricultural policy analysis and decision support system - The platform Construction of the agricultural strategic analysis and its expansion, opening and communication for "Belt and Road Initiative". Y2018PT31, 2018"; "Construction of Portal and Platform of Agricultural Economic Theory, Policy Analysis and remote Scientific Research Environment. 161005201902-1 2019".

\begin{abstract}
Computable General Equilibrium (CGE) models are mostly used for agricultural market analysis globally. This paper constructs a Computable General Equilibrium model using Global Trade Analysis Project (GTAP) model followed by the GTAP 9A database. The primary aim of this paper is to analyze the potential impact of tariff increase on Agricultural crop sectors (Rice and Wheat) in Bangladesh and then describes the construction of the database. It also attempts to detect the trend of the tariff change impact on rice and wheat production in Bangladesh and other South Asian countries. Using database reference year 2011, this paper builds a computable general equilibrium model to measure the Tariff impact in Bangladesh. Result of the model suggests that if an import tariff is imposed, it will affect domestic-foreign relative price between Bangladesh and other south Asian countries. Bilateral trade between Bangladesh and South Asia country will decline sharply. Finally, this paper explained the policy scenario, data sources, and processing methods in details.
\end{abstract}

Keywords: Computable General Equilibrium (CGE) analysis, agriculture, transitional economies, Bangladesh, south Asian country

\section{Introduction}

Bangladesh is located in South Asia and a low-lying, riverine country with a largely marshy jungle coastline of $710 \mathrm{~km}$ on the northern coast, total area 147,570 square kilometers. The economy of Bangladesh is mainly agriculture based, with almost $70 \%$ of the population directly or indirectly relying on agricultural activities. Agriculture is a key economic sector in Bangladesh, accounting for 65 percent of the labor force and mostly rural households will continue to depend on the agriculture sector for income and livelihoods. Bangladesh population is about 164.66 million (World Bank) and majority of the population depends on rice for their daily meal and rice is the main staple food in Bangladesh which accounts for around $70 \%$ of daily caloric intake (Ricepedia, 2016). In fact, Bangladeshis are probably the largest per capita consumers of rice in the world today. People of Bangladesh take more rice rather other cereals, vegetables \& fruits and animal protein. Rice is Bangladesh's largest crop and its role in the economy is huge both at the macro level and at the micro level. Rice cultivation accounts for 48 percent of total rural employment (of both men and women in production), and is expected to rise even more if rice trading, transport and processing activities are also taken into account. Its contribution to agricultural GDP is about 70 percent while its share of national income is one-sixth. Although Bangladesh people are usually called rice eater wheat also the second consumed crop beside rice. Wheat is basically a winter crop in Bangladesh and is temperature sensitive and the second most important grain crop after rice. It occupies around $4 \%$ of the total cropped area and $11 \%$ of the area cropped in rabi (winter crops starting from November to February), and contributes 7\% to the total output of food cereals (Anonymous, 2008). Wheat often generates 
the highest returns in non-irrigated zones and in areas that are unsuitable for rice production and contribute to national economy of Bangladesh.

In fact rice is among the three leading food crops of the world, with maize (corn) and wheat being the other two. Bangladesh and other South Asia countries are the major rice producing country in the world. Although South Asian countries are dominated by agriculture and the development is relatively slow and even negative economic growth. It is very important that the South Asian region's economy could get out of the economic development dilemma, enhance the industrial upgrading and integration, and realize the purpose of building and sharing the model between economy member states. However, due to the small amount of long-term agricultural trade, the unreasonable structural layout, the location advantage is not obvious, and the existence of trade barriers lessen agricultural trade cooperation between Bangladesh and other South Asian countries. Proper Agricultural strategy will help Bangladesh to integrate into the new global development pattern with South Asia and make a strong driving force for Bangladesh to develop and implement a new strategy of economic development. Based on above, this paper tries to analyze the tariff policies in Bangladesh, especially agricultural strategy based on the general equilibrium model. The main objective of this paper is to examine the possible outcome of tariff impact, using CGE model on Bangladesh in particular. The rest of the paper will analyze the tariff increase scenario and its possible impact on Bangladesh economy using Global Trade Analysis Project (GTAP) model.

\section{A CGE Model for Tariff Policy}

There are two different approaches to analyze the impacts of policy changes one is partial equilibrium and the other is general equilibrium. Partial equilibrium models are comparatively simple and evaluate the impacts of policy changes on few selected sectors of the economy. On the other hand, general equilibrium models are comparatively complex and evaluate the economy-wide impact of a policy change precisely. In the year 2016 Leif Johansen established a multi-sectoral growth model for study the economic growth in Norway, which means the beginning of CGE model. He chose to construct an empirical model, calibrated to fit the Norwegian economy in 1950. Johansen's model combined Leontief's input-output analysis with Solow-type production functions and a Frisch-influenced specification of consumption demand. His work became influential on the further CGE development and CGE model are developing very quickly day by day from then. Almost all the developing and developed countries have already adopted their own CGE model and among this GTAP model is the most famous model in worldwide. The Global Trade Analysis Project has become one of the most widely used analytical tools for solving CGE models. The GTAP model first built by Purdue University in the United States and has been widely used in research and analysis, and its application involves tariff reductions and financial research. Global Trade Analysis Project (GTAP) model has been extensively used in Tariff and other Trade related studies to evaluate the economy-wide potential impact of economic policy reforms. So for our analysis we selected the widely used general equilibrium model in trade called Global Trade Analysis Project (GTAP). This paper analyzes the tariff policy simulation using Global Trade Analysis Project (GTAP). Therefore, this paper will attempt to make tariff policy impacts on related variables, draw the model and theories in the relevant literature to conduct a comprehensive analysis, and propose more reasonable, feasible, realistic and relevant policy measurement.

\subsection{Background of the General Equilibrium Models}

Computable general equilibrium (CGE) model is mostly used for quantitative analysis of economics and public finance policies. It can be used for simulation forecasting in national economy, trade, environment, fiscal taxation, public policy, Quantitative tools, etc. CGE modeling specifies economic relationship in mathematical terms that allows predict the changes in price, output and change in economic policies. To do this model requires information about consumer preferences, technology and policies. The key of the model is the market clearing condition that says supply should equal demand in every market. This study used GTAP as the solution software and analyzes the economic impact, and then makes simulation for the changes in economic indicators of Bangladesh and other South Asian countries.

\subsection{The Global Trade Analysis Project}

Hertel (1997) provides detail information about the structure and overview of GTAP model. GTAP model is a multi-regional CGE model which includes world economic activity in 57 different sectors of 140 regions (Version 9A). The equation system of GTAP includes two different kinds of equations. One part of equation includes the accounting relationships between receipts and expenditures of every agent in the economy are balanced. The other part is the behavioral equations based on microeconomic theory. Input-output tables in this model make linkage between all agents and industries. Mathematical relationship assumed in the GTAP model is that thousands of markets are aggregated into groups. For example transport and communication service on 
database appeared in a single group. In the GTAP model relationship such as international trade elasticities and the agricultural factor supply and demand elasticities have been econometrically estimated.

\subsection{Data}

This paper utilized Global Trade Analysis Project (GTAP) Database version 9A. The entire GTAP database covers the global economy with 140 regional units and bilateral trade data for 57 products and services which, together, exhaust global economic activity with reference year 2004, 2007 and 2011. The Data Base presents globally consistent data on consumption, production, and international trade (including transportation and protection data), energy data and carbon dioxide $\left(\mathrm{CO}_{2}\right)$ emissions data. The core data consist of economic value flows valued in millions of current US dollars (i.e., valuation differs according to the reference year). The latest reference year 2011 is used in the model calibration and this model represents the world economy in 2011. The tariff data is mainly in the form of applied ad valorem rates.

\subsection{Aggregation and Structure of This Paper}

GTAP provides an economy-wide framework for analysis the interdependencies within and between countries. The model includes; industrial sectors, households and governments across the countries. GTAP core database includes in this model are 57 sectors and 140 regions. The current study has aggregated 57 commodities into 13, and 140 regions into 7. Regions include Bangladesh, India, Nepal, Pakistan, Sri Lanka, Rest of South Asia and the Rest of the World. Sectors include Rice, Wheat, Vegetable, Grain Crops, MeatLstk, Extraction, Process Food, TextileWapp, Light Manufacturing, Heavy Manufacturing, Util Cons, Transport Communication and Other Services.

Table 1. Model aggregation

\begin{tabular}{lll}
\hline Regions & Sectors & Factors \\
\hline Bangladesh & Rice & Land \\
India & Wheat & UnSkLab \\
Nepal & Vegetable & SkLab \\
Pakistan & Grain Crops & Capital \\
Sri Lanka & MeatLstk & NatRes \\
Rest of South Asia & Extraction & \\
Rest of World & Process Food & \\
& TextileWapp & \\
& Light Manufacturing & \\
& Heavy Manufacturing & \\
& Util Cons & \\
& Transport Communication & \\
& Other Services & \\
\hline
\end{tabular}

Source: Author Generation.

However, there is no independent rice and wheat sector in GTAP 9A database and it is included in "GrainsCrops ('Grains and Crops')" sector. It is necessary to separate rice and wheat from GrainsCrops. So this study added new sectors ("rice and wheat") into GTAP 9A database. Factors of production were aggregated into Land, Skilled Labor, Unskilled Labor, Capital, and Natural Resources category. The data is calibrated at first meaning the model is solved for its original equilibrium prices and volumes in all markets and this meant to represent the economy before shock level. Thousands of equations are created in this model which representing supply and demand conditions in markets inside each region, including markets for services, factors of production, goods, savings, government expenditure, and more. The shock created in this model is the tariff increase into the rice and wheat sectors in Bangladesh. For example 20 percent tariff increase on rice and 10 percent tariff increase on wheat are implemented in Bangladesh. The magnitude of the shock will bring relative changes in the economy and this will be analyses in the next part of this paper.

\subsection{Policy Simulation}

We used GTAP static model for our analysis and the model assumes perfect competition, constant return to scale and profit and utility maximizing behavior of firms and household respectively. We build two different scenarios on the main GTAP model to analyze the possible tariff impacts between Bangladesh and other South Asia Country. 
On main GTAP model shocks section, at first scenario we increased rice tariff 20 percent and then in second scenario we increased 10 percent tariff on Wheat to know the economic output between Bangladesh and other South Asia Country. The variable that simulates the impact of the policy is the tariff and GTAP 9A database tariff code is (tms), which will effects the final policy results by increasing tariffs. Increase on tariff will systematically influence on import and export prices, which in turn affects the domestic market price and the volume of imports and exports of products and Output volume. The Tablo language of this tariff increasing formulae is:

$$
\begin{gathered}
\operatorname{tms}(\mathrm{i}, \mathrm{r}, \mathrm{s})=\operatorname{pms}(\mathrm{i}, \mathrm{r}, \mathrm{s})-\operatorname{tm}(\mathrm{i}, \mathrm{s})-\operatorname{pcif}(\mathrm{i}, \mathrm{r}, \mathrm{s}) \\
\operatorname{pcif}(\mathrm{i}, \mathrm{r}, \mathrm{s})=\operatorname{FOBSHR}(\mathrm{i}, \mathrm{r}, \mathrm{s}) \times \operatorname{pfob}(\mathrm{i}, \mathrm{r}, \mathrm{s})+\operatorname{TRNSHR}(\mathrm{i}, \mathrm{r}, \mathrm{s}) \times \operatorname{ptrans}(\mathrm{i}, \mathrm{r}, \mathrm{s}) \\
\operatorname{pfob}(\mathrm{i}, \mathrm{r}, \mathrm{s})=\operatorname{pm}(\mathrm{i}, \mathrm{r})-\operatorname{tx}(\mathrm{i}, \mathrm{r})-\operatorname{txs}(\mathrm{i}, \mathrm{r}, \mathrm{s}) \\
\operatorname{pim}(\mathrm{i}, \mathrm{s})=\operatorname{sum}(\mathrm{k}, \mathrm{REG}, \operatorname{MSHRS}(\mathrm{i}, \mathrm{k}, \mathrm{s}) \times[\operatorname{pms}(\mathrm{i}, \mathrm{k}, \mathrm{s})-\operatorname{ams}(\mathrm{i}, \mathrm{k}, \mathrm{s})]) \\
\mathrm{qo}(\mathrm{i}, \mathrm{r})=\operatorname{SHRDM}(\mathrm{i}, \mathrm{r}) \times \mathrm{qds}(\mathrm{i}, \mathrm{r})+\operatorname{sum}(\mathrm{s}, \mathrm{REG}, \operatorname{SHRXMD}(\mathrm{i}, \mathrm{r}, \mathrm{s}) \times \mathrm{qxs}(\mathrm{i}, \mathrm{r}, \mathrm{s})+\operatorname{tradslack}(\mathrm{i}, \mathrm{r})
\end{gathered}
$$

where, PMS(i,r,s) Indicates Importer's domestic price of commodity (i) supplied from region (r) to region (s), $\mathrm{TM}(\mathrm{i}, \mathrm{s})$ Indicates change in tax on imports of commodity (i) into Country (s), TMS(i,r,s) Indicates changes in the power of bilateral import taxes(tariff), PCIF (i,r,s) Indicates CIF price of commodity (i) supplied from region (r) to region (s), FOBSHR(i,r,s) refers to weights of fob costs shares, TRNSHR(i,r,s) refers to transport costs in cif costs, PFOB(i,r,s) Indicates FOB price of commodity i supplied from region $r$ to region s, PM(i,r) Indicates Domestic price of commodity i in region r, TX(i,r) (destination-generic) Indicates change in subsidy on exports of commodity $\mathrm{i}$ from region $\mathrm{r}$. Equation 1 describes the tariff, equation 2 links between pcif(i,r,s) and pfob(i,r,s) and equation 3 completes the price links by connecting pfob(i,r,s) and domestic market price.

\section{Model Simulation Results and Analysis}

\subsection{Impact on GDP}

Bangladesh agriculture sector comprises of crops, forests, fisheries and livestock. Of the agricultural GDP, the crop sub-sector contributes 71 per cent and crop sectors share is nearly $55 \%$ of the national employment (Anonymous Source). Although Agricultural sectors contribution to GDP gradually decreases over the last few decades. Our simulation results suggest a clear view for Bangladesh among all trading partners in south Asian country, at least in terms of GDP percentage changes. Indeed, after levied tariff on Rice and Wheat we can see that Bangladesh GDP decreases slightly (-0.002 percent) compared to pre simulation scenario and it will effects on Bangladesh economy slightly. The projection is optimistic for India and Nepal, with a slight GDP percentage increase. Meanwhile Sri Lanka, Pakistan and the rest of the south Asia's GDP decreases slightly. Rice and wheat export from other south Asian country could divert to other country as Bangladesh levied tariff on Rice and Wheat and Bangladesh could lose South Asia market integration (See Table 2).

Table 2. Model simulation, changes in GDP quantity index (million dollars)

\begin{tabular}{llll}
\hline qgdp & Pre Scenario & Post Scenario & Change in Percentage \\
\hline Bangladesh & 111905.7 & 111903.56 & -0.001927 \\
India & 1880101 & 1880101.6 & 0.00005 \\
Nepal & 18850.36 & 18850.395 & 0.00019 \\
Pakistan & 213686.2 & 213685.77 & -0.00019 \\
Sri Lanka & 59178.04 & 59177.984 & -0.00009 \\
Xsa(Rest of South Asia) & 21873.94 & 21873.93 & -0.00005 \\
RestofWorld & 69171552 & 69171560 & 0.00001 \\
\hline
\end{tabular}

Source: Generated by Author.

\subsection{Impact on Trade Balance}

The increase of tariff on rice and wheat results in changes to trade balance into Bangladesh and south Asian countries. As shown in Table 3, Bangladesh a major partner of rice producing country, experiences by 17.345 million dollars increase in its trade balance. From our simulation result it is clear that the trade balance is higher in Bangladesh compared to other south Asia country and the rest of the world. South Asian countries are the exporter and importer of rice and wheat. Overall south Asia experiences a slight decrease and increase in trade balance. Pakistan and the rest of the south Asia experience a slight increase in trade balance on the other hand Sri 
Lanka, Indian and Nepal experiences a slight decrease on trade balance. Meanwhile rest of the world experiences by 16.79 million dollars decrease in its trade balance.

Table 3. Model simulation, change in trade balances (millions of dollars)

\begin{tabular}{ll}
\hline DTBAL & Change \\
\hline Bangladesh & 17.345 \\
India & -0.525 \\
Nepal & -0.446 \\
Pakistan & 0.424 \\
Sri Lanka & -0.04 \\
xsa (Rest of South Asia) & 0.039 \\
RestofWorld & -16.798 \\
\hline
\end{tabular}

Source: Generated by Author.

Changes in trade balances by sector provide evidence of decreeing trade in Bangladesh and other south Asia country. As presented in Table 4, Bangladesh rice export tends to increase by 0.08 million dollars and wheat export increase by 46.12 million dollars. Meanwhile process food exports fall by 44.44 million dollars, vegetable export fall by 0.54 million dollars and grain crops export fall by 0.049 million dollars in Bangladesh which will effect on overall economy in Bangladesh.

Table 4. Model simulation, change in trade balances by sector (millions of dollars)

\begin{tabular}{llllllll}
\hline DTBALi & Bangladesh & India & Nepal & Pakistan & Srilanka & xsa & RestofWorld \\
\hline Rice & 0.081 & -0.212 & -0.005 & 0.293 & 0 & -0.002 & -0.165 \\
Wheat & 46.121 & -2.879 & 0 & -7.7 & 0.006 & -0.008 & -32.121 \\
Vegetable & -0.54 & 0.019 & -0.007 & 0.414 & -0.007 & 0.004 & -0.028 \\
GrainsCrops & -0.049 & -0.141 & -0.029 & 1.136 & -0.005 & -0.005 & -0.987 \\
MeatLstk & -0.514 & -0.003 & -0.005 & 0.271 & 0 & 0.004 & 0.198 \\
Extraction & 1.8 & 0.033 & -0.01 & 0.013 & -0.001 & -0.002 & -1.971 \\
ProcFood & -44.444 & 4.152 & -0.008 & 0.778 & 0.047 & 0.01 & 36.874 \\
TextWapp & 7.395 & -0.503 & -0.103 & 2.328 & -0.043 & 0.001 & -9.378 \\
LightMnfc & 2.292 & -0.375 & -0.065 & 1.457 & -0.012 & 0.003 & -3.324 \\
HeavyMnfc & 3.122 & -0.366 & -0.056 & 1.185 & -0.018 & 0.005 & -3.991 \\
Util_Cons & 0.073 & 0 & -0.009 & 0.01 & 0 & 0.007 & -0.08 \\
TransComm & 0.195 & -0.053 & -0.065 & 0.132 & -0.004 & 0.01 & -0.175 \\
OthServices & 1.813 & -0.196 & -0.082 & 0.107 & -0.003 & 0.011 & -1.651 \\
\hline
\end{tabular}

Source: Generated by Author.

Outside Bangladesh other south Asian country trade effects are significant. The rest of the world faces the worst scenario compared to South Asia region. The rest of the world wheat export decline by 32.12 million dollars, rice export decline by 0.165 million dollars compared to countries in South Asia. Meanwhile process food export increases by 36.87 million dollars in the rest of the world. While Bangladesh trade balance in wheat and rice expands, trade balance in India, rest of the south Asia and the rest of the world declines in rice and wheat.

\subsection{Impact on Export and Import}

Overall, the change in sectorial production can be explained by changes in export and import performance in each sector. Exports and Imports can be individually examined. In Bangladesh, tariff increase results in a 0.436 percent decrease in rice export, followed by significant decrease in exports of wheat (-12.906 percent), vegetables (-0.155 percent), grain crops (-0.097 percent) and process food (-3.161 percent). These results again indicate challenges for Bangladesh agricultural sector, as well as for ongoing poverty reduction and economic development, since most poor households live in rural areas and are highly dependent on agricultural production for their livelihoods. On the other hand, rice and wheat export of India, Nepal and the rest of the world decreases. Meanwhile Pakistan rice export increases by 0.14 percent. Changes in aggregate exports are presented in Table 5. 
Table 5. Model simulation, change in aggregate exports by sector (percent)

\begin{tabular}{llllllll}
\hline qxw & Bangladesh & India & Nepal & Pakistan & Srilanka & xsa & RestofWorld \\
\hline Rice & -0.436 & -0.079 & -0.086 & 0.14 & -0.011 & -0.04 & -0.001 \\
Wheat & -12.906 & -2.297 & -0.083 & -0.873 & 0.07 & 0.042 & -0.06 \\
Vegetable & -0.155 & 0.002 & 0.017 & 0.045 & -0.003 & 0.005 & 0 \\
GrainsCrops & -0.097 & -0.001 & -0.023 & 0.04 & 0 & 0.002 & 0 \\
MeatLstk & -1.185 & 0 & -0.031 & 0.118 & -0.001 & 0.006 & 0 \\
Extraction & 0.474 & -0.001 & -0.038 & 0.008 & -0.001 & -0.001 & 0 \\
ProcFood & -3.161 & 0.029 & 0 & 0.029 & 0.004 & 0.01 & 0.005 \\
TextWapp & 0.041 & -0.002 & -0.024 & 0.018 & -0.002 & 0 & -0.001 \\
LightMnfc & 0.081 & -0.001 & -0.025 & 0.038 & -0.001 & 0.002 & 0 \\
HeavyMnfc & 0.14 & 0 & -0.013 & 0.009 & 0 & 0.001 & 0 \\
Util_Cons & 0.171 & 0 & -0.024 & 0.008 & 0 & 0.002 & 0 \\
TransComm & 0.04 & 0 & -0.017 & 0.005 & 0 & 0.001 & 0 \\
OthServices & 0.105 & 0 & -0.02 & 0.006 & 0 & 0.001 & 0 \\
\hline
\end{tabular}

Source: Generated by Author.

Import patterns are also affected. In Bangladesh, imports of wheat ( -4.35 percent), and rice ( -0.7 percent) decreases because of tariff increase on rice and wheat sector. Import increase in other sectors in Bangladesh, including vegetable ( 0.6 percent), process food ( 0.8 percent). Basically tariff will raises the price of rice and wheat imported in Bangladesh, making it more expensive than similar domestic goods. On the other hand, in India, Nepal, Sri Lanka and the rest of the world rice and wheat import increases slightly compared to Bangladesh (See Table 6).

Table 6. Model simulation, change in aggregate imports by sector (percent)

\begin{tabular}{llllllll}
\hline qiw & Bangladesh & India & Nepal & Pakistan & Srilanka & xsa & RestofWorld \\
\hline Rice & -0.734 & 0.001 & 0.03 & -0.063 & 0.006 & -0.006 & 0.006 \\
Wheat & -4.349 & 0.003 & 0.037 & -0.222 & 0.011 & 0.038 & 0.001 \\
Vegetable & 0.059 & 0.001 & 0.011 & -0.026 & 0.002 & 0.009 & 0 \\
GrainsCrops & -0.009 & -0.006 & 0.009 & -0.016 & 0.002 & 0.006 & 0 \\
MeatLstk & 0.467 & -0.001 & 0.013 & -0.046 & 0 & -0.001 & 0 \\
Extraction & -0.08 & 0 & 0.006 & 0 & 0 & 0 & 0 \\
ProcFood & 0.824 & -0.004 & -0.004 & -0.013 & 0 & 0.001 & -0.001 \\
TextWapp & 0.012 & 0.001 & 0.004 & -0.004 & -0.001 & 0 & 0 \\
LightMnfc & -0.068 & 0 & 0.008 & -0.015 & 0 & 0 & 0 \\
HeavyMnfc & -0.016 & 0 & 0.001 & -0.003 & 0 & 0 & 0 \\
Util_Cons & -0.115 & 0 & 0.004 & -0.004 & 0 & 0 & 0 \\
TransComm & -0.012 & 0 & 0.009 & -0.003 & 0 & 0 & 0 \\
OthServices & -0.043 & 0 & 0.009 & 0 & 0 & 0 & 0 \\
\hline
\end{tabular}

Source: Generated by Author.

\subsection{Impact on Output Volume}

Changes in the output volume reflect the same pattern also. In Bangladesh, wheat production increase, but decrease in almost every other sector. In Bangladesh wheat production increase by 9.45 percent, while output fall in rice (-0.046 percent), Graincrops (-0.56 percent), process food ( -0.912 percent) and vegetables ( -0.031 percent). Although tariff provides a source of revenue for the country levying them, tariffs could reduce Bangladesh output through a few channels. One possibility is that a tariff may cause higher price which finally affects both producers and consumers in Bangladesh. Across the south Asia country wheat output declines in India (-0.01 percent), Pakistan (-0.09 percent) and the rest of the south Asia ( -0.005 percent). The results are presented in Table 7. 
Table 7. Model simulation, change in output volume by sector (percent)

\begin{tabular}{llllllll}
\hline qo & Bangladesh & India & Nepal & Pakistan & Srilanka & xsa & RestofWorld \\
\hline Rice & -0.046 & 0 & 0 & 0.011 & 0 & 0 & 0 \\
Wheat & 9.45 & -0.01 & 0.001 & -0.09 & 0.002 & -0.005 & -0.019 \\
Vegetable & -0.031 & 0 & 0 & 0.012 & 0 & -0.002 & 0 \\
GrainsCrops & -0.056 & 0 & -0.001 & 0.005 & 0 & 0 & 0 \\
MeatLstk & 0.041 & 0 & 0.001 & 0.006 & 0 & 0.001 & 0 \\
Extraction & -0.02 & 0 & -0.002 & 0.003 & 0 & 0 & 0 \\
ProcFood & -0.912 & 0.003 & 0.003 & 0.001 & 0.001 & 0.003 & 0.001 \\
TextWapp & 0.038 & -0.001 & -0.014 & 0.007 & -0.001 & 0 & -0.001 \\
LightMnfc & -0.011 & 0 & -0.005 & 0.005 & 0 & 0.001 & 0 \\
HeavyMnfc & 0.068 & 0 & -0.005 & 0.002 & 0 & 0 & 0 \\
Util_Cons & -0.027 & 0 & 0.003 & 0.001 & 0 & 0 & 0 \\
TransComm & 0.012 & 0 & -0.001 & 0.002 & 0 & 0 & 0 \\
OthServices & 0.019 & 0 & 0 & 0.001 & 0 & 0 & 0 \\
CGDS & -0.043 & 0 & 0.005 & 0.003 & 0 & 0 & 0 \\
\hline
\end{tabular}

Source: Generated by Author.

As can be seen, Wheat production substantially increases by 9.45 percent, to meet the demand of an increasingly population in Bangladesh. In spite of this growth, the wheat sector still remains relatively small in the Bangladesh economy.

\subsection{Impact on Market Price}

Changes in output and trade reflect changes in market price. In Bangladesh, the market price of rice increase by 0.05 percent (although Bangladesh is largely self-sufficient in rice production), wheat increases by 1.6 percent, vegetable increases by 0.05 percent and Grain Crops increase by 0.2 percent. The increases in tariff result in increase in market prices. Besides, in Nepal market price in rice and wheat increases the same by 0.006 percent, while in Pakistan decreases. India and the rest of the world remain the same decrease on wheat by 0.002 percent, the rest of south Asia decreases by 0.002 percent on rice and 0.004 percent on wheat (See Table 8).

Table 8. Model simulation, change in market price by sector (percent)

\begin{tabular}{llllllll}
\hline pm & Bangladesh & India & Nepal & Pakistan & Srilanka & xsa & RestofWorld \\
\hline Land & 0.275 & -0.001 & 0.006 & -0.085 & 0 & -0.004 & -0.003 \\
UnSkLab & -0.023 & 0 & 0.006 & -0.011 & 0 & -0.001 & 0 \\
SkLab & -0.03 & 0 & 0.006 & 0 & 0 & 0 & 0 \\
Capital & -0.051 & 0 & 0.006 & -0.001 & 0 & 0 & 0 \\
NatRes & -0.194 & 0 & -0.007 & 0.013 & 0 & 0.001 & 0 \\
Rice & 0.048 & 0 & 0.006 & -0.017 & 0 & -0.002 & 0 \\
Wheat & 1.623 & -0.002 & 0.006 & -0.053 & -0.011 & -0.004 & -0.002 \\
Vegetable & 0.047 & 0 & 0.006 & -0.018 & 0 & -0.003 & 0 \\
GrainsCrops & 0.024 & 0 & 0.006 & -0.01 & 0 & -0.002 & 0 \\
MeatLstk & 0.173 & 0 & 0.006 & -0.017 & 0 & -0.001 & 0 \\
Extraction & -0.049 & 0 & 0.004 & -0.001 & 0 & 0 & 0 \\
ProcFood & 0.758 & 0 & 0.005 & -0.006 & -0.001 & -0.002 & 0 \\
TextWapp & -0.006 & 0 & 0.003 & -0.003 & 0 & 0 & 0 \\
LightMnfc & -0.013 & 0 & 0.004 & -0.006 & 0 & 0 & 0 \\
HeavyMnfc & -0.021 & 0 & 0.002 & -0.001 & 0 & 0 & 0 \\
Util_Cons & -0.037 & 0 & 0.005 & -0.002 & 0 & 0 & 0 \\
TransComm & -0.012 & 0 & 0.005 & -0.002 & 0 & 0 & 0 \\
OthServices & -0.027 & 0 & 0.005 & -0.001 & 0 & 0 & 0 \\
CGDS & -0.03 & 0 & 0.004 & -0.002 & 0 & 0 & 0 \\
\hline
\end{tabular}

Source: Generated by Author.

\section{Conclusion}

Agricultural activities in general and the rice and wheat activities in particular are of special interest in this paper. The objective of this paper was to analyze the impact of tariff increase on rice and wheat in Bangladesh using a 
static GTAP model. Bangladesh should always consider taking a balanced approach to development. The results of this experiment suggest that tariff increase will have a marginally positive impact in Bangladesh. Trade balance in Bangladesh increased compared to other south Asian country, performance in export and import of wheat markets shows a considerable decline and rice markets decreases a slight, and this will make no adverse impact on overall economy because Bangladesh is a self-sufficient rice producing country. On the other hand rice output decrease slight while increased output of wheat would definitely increase the welfare of its citizens. Increased Wheat output appears to hit rice, vegetables, Grain Crops, Process Food sectors even more negatively compared to other south Asian country. Market price of both rice and wheat also increases more compared to other south Asian country. The impact varies across household groups because of differences in the structure of expenditure. In order to increase welfare of low-income rice producing households, policy maker might focus on other complementary policy options such as increase productivity or improve market transparency. Therefore, the most important policy purpose of Bangladesh is to promote its rice and wheat production efficiency. In addition to government policy and financial support technical improvement of rice and wheat sector would be beneficial in future. In other words, Bangladesh's rice and wheat production system needs innovative technology progress, if it wants to have a better performance in trade balance in future. Finally if Bangladesh wants to be more integrated with south Asian market then Bangladesh government need to make a multilateral policy between Bangladesh and south Asian country but need to think about local farmers welfare before implement any policy.

\section{Acknowledgements}

I would like to thanks to project named "Open Laboratory of national agricultural policy analysis and decision support system" and "Construction of Portal and Platform of Agricultural Economic Theory, Policy Analysis and remote Scientific Research Environment” for the grant. Finally I would like to thanks Professor Huang Delin for his assistance and instruction in conducting the study and manuscript preparation.

\section{References}

Aguiar, A., Narayanan, B., \& Robert, M. D. (2016). An Overview of the GTAP 9 Data Base. Journal of Global Economic Analysis, 1(1), 181-208. https://doi.org/10.21642/JGEA.010103AF

Ali, A. (2017). A CGE Analysis of Pakistan-Turkey Free Trade Agreement (MPRA Paper No. 78318). Retrieved from https://mpra.ub.uni muenchen.de/78318

Bjerkholt, O. (2009). The Making of the Leif Johansen Multi-Sectoral Model, History of Economic Ideas.

Hertel, T. W. (1997). Global Trade Analysis: Modelling and Applications. Cambridge University Press, USA.

Hossain, A., \& Jaime, A. T. da S. (2012). Wheat production in Bangladesh: Its future in the light of global warming. AoB PLANTS, 5, 2013, pls042. https://doi.org/10.1093/aobpla/pls042

Karim, M. R., Baset, M. A., Alam, Q. M., \& Hossain, S. (2008). Contribution of Bari Cereal Crops to The National GDP of Bangladesh. Bangladesh J. Agril. Res., 33(3), 565-570. https://doi.org/10.3329/bjar. v33i4.2289

Michael, P. B. (2009). Foreign Direct Investments in Central Asian Energy: A CGE Model. Eurasian Journal of Business and Economics, 2(3), 35-54.

Pham, V. H., Kompas, T., Nguyena, H. T. M., \& Long, C. H. (2017). Building a better trade model to determine local effects: A regional and intertemporal GTAP model. Economic Modeling, 67, 102-113. https://doi.org/ 10.1016/j.econmod.2016.10.015

Sayeed, K. A., \& Yunus, M. M. (2018). Rice prices and growth, and poverty reduction in Bangladesh. Food and Agriculture Organization of the United Nations.

Sharma, S. K., \& Kallummal, M. (2012). A GTAP Analysis of the Proposed BRICS Free Trade Agreement. 15th Annual Conference on Global Economic Analysis, Geneva, Switzerland.

\section{Copyrights}

Copyright for this article is retained by the author(s), with first publication rights granted to the journal.

This is an open-access article distributed under the terms and conditions of the Creative Commons Attribution license (http://creativecommons.org/licenses/by/4.0/). 